\title{
SCREENING OF ANTIOXIDANT PROPERTY IN MEDICINAL PLANTS BELONGING TO THE FAMILY APOCYNACEAE
}

\author{
ZAHRA IQBAL ${ }^{1}$, MOHAMMED SHARIQ IQBAL ${ }^{2 *}$, KUMKUM MISHRA $^{1}$
}

${ }^{1}$ Department of Botany, University of Lucknow, Lucknow - 226 007, Uttar Pradesh, India. ${ }^{2}$ Amity Institute of Biotechnology, Amity University Uttar Pradesh, Lucknow - 226 028, Uttar Pradesh, India. Email: msiqbal@lko.amity.edu

Received: 29 August 2017, Revised: 05 October 2017 and Accepted: 23 October 2017

\begin{abstract}
Objective: The present study was aimed to explore antioxidant properties of the plants belonging to the family Apocynaceae.

Methods: Plants used in the study were Alstonia scholaris, Calotropis gigantea, Catharanthus roseus, Cerbera odollam, and Wrightia tinctoria. The plant material was used to estimate non-enzymatic antioxidant, namely, total antioxidant, total flavonoids, total phenolic, and total carotene content using spectrophotometer.
\end{abstract}

Result: The results showed significant antioxidant potential of the plants used in the study. It was observed that total flavonoids content was maximum in W. tinctoria (65.21 $\pm 3.712 \mathrm{mg}$ equivalent quercetin/g of tissue), while total phenolic content was found maximum in C. roseus (59.63 $\pm 2.151 \mathrm{mg}$ equivalent gallic acid/g of tissue). When total carotene content and total antioxidant activity were estimated, it was found maximum in $C$. roseus with (70.91 $\pm 4.41 \mu \mathrm{g} / \mathrm{g}$ fresh weight) and (0.846 $\pm 0.109 \mathrm{mM}$ equivalent ascorbic acid/g tissue), respectively.

Conclusion: It was observed C. roseus possess potent antioxidant property compared with other plants of same family. When correlation was established between the antioxidants and different genera plants, a strong positive correlation was observed, indicating that the plants belonging to the family Apocynaceae are a potent source of antioxidants. Further research is recommended to explore this family (Apocynaceae) and to fully elucidate its biochemical (antioxidant) benefits.

Keywords: Apocynaceae, Antioxidant, Catharanthus roseus, Carotene, Flavonoid, Phenolic.

(C) 2017 The Authors. Published by Innovare Academic Sciences Pvt Ltd. This is an open access article under the CC BY license (http://creativecommons. org/licenses/by/4. 0/) DOI: http://dx.doi.org/10.22159/ajpcr.2017.v10i12.22303

\section{INTRODUCTION}

Plant phytochemicals play significant role in the advancement of numerous clinically valuable medications [1]. It is usually believed that plant-based medications are healthier than artificial drugs as these are non-toxic for human beings. Phytochemicals work as nutrients and dietary fiber to defend against various diseases. Phytochemicals are synthesized as secondary metabolites, which are present in minor amount in higher plants. Usually, they include steroids, alkaloids, flavonoids, tannins, terpenoids, and several others [2]. Many phytochemicals possess antioxidative property, which can lessen the danger of many diseases [3]. The prominence of therapeutic plants and the impact of phytomedicine derived from it have a significant influence to the well-being of the considerable world population, which have engrossed awareness from different disciplines of research. Antioxidants defend our body cells against the adverse effects of free radicals produced in our body. These free radicals are produced during oxidative breakdown of our food to simpler compounds. They might also be produced in our body by environmental exposures such as radiation and smoke. Free radicals may harm cells, and play a role in cancer, cardiovascular disease, and various other diseases. Aerophilic damage causes probably break down or perhaps hardening of lipids, which is the most important constituent of all cell walls. This breakdown or hardening is because of macromolecule peroxidation and ends up in death of cell or loss of traditional cell perform. In addition, alternative biological molecules as well as RNA, DNA, and supermolecule enzymes are vulnerable to aerophilic injury. Environmental agents initiate radical generation that ends up in completely different complications in body. The toxicity of lead, pesticides, cadmium, radiation, alcohol, cigarette smoke, ultraviolet radiation, and pollution could all ensure to their radical initiating capability $[4,5]$. Antioxidants cause defensive impact by counteracting free radicals that are toxic by-products of natural cell metabolism. Our body naturally forms antioxidants, but the process is not very much effective in case of devastating formation of free radicals and the efficiency also declines with age [6]. Consuming increased level of antioxidant can inhibit several diseases and lesser health-related problems. Investigations are progressively showing that foods and herbs rich in antioxidants have enormous health benefits. Remedial aromatic plants are the chief sources of antioxidant compounds [7].

The family Apocynaceae includes about 1500 species that are bifurcated over about 424 genera. Plants of the family are native to Australian, Asian, European, African, and American tropics or subtropics, with several temperate members [8]. Several species are tall trees that are found in tropical rainforests. However, some grow in tropical dry environments also [9]. There are some perennial herbs that are found in temperate zones [10]. Many of the plants of this family are the sources of important drugs, such as cardiac glycosides, which is effective in heart functioning [11]. Rapanarivo and Leeuwenberg [12] reported Catharanthus roseus is rich in alkaloid content, which can be used in the treatment of cancer. The plant is a potent source of antioxidants.

The aim of study is to explore whether the plants possess antioxidant properties that might be accountable for their action against oxidative damage. The presence of phenols, flavonoids, and carotene in the plant materials was investigated and trailed by rapid screening for free radical scavenging activity. Correlation between total antioxidant activity, total phenolic, total flavonoid, and total carotene contents was also investigated to establish relationship between these groups of plants. In this study, the antioxidant capacity of biomass may expedite to formulate the composition of nutraceutical/pharmaceutical and herbal products, enriched with antioxidant for human well-being. 


\section{METHODS}

\section{Plant material}

Samples were collected from plants growing in herbal garden at Amity University, Uttar Pradesh, Lucknow campus, and nearby localities (Council of Scientific and Industrial Research - National botanical research institute and herbal garden at University of Lucknow). Plants used in the study were Alstonia scholaris, Calotropis gigantea, C. roseus, Cerbera odollam, and Wrightia tinctoria. For extraction and analysis, only fresh plant leaves were taken and washed with sterile water. The leaves were blot dried and then used in the study. The leaves were homogenized and extracted accordingly for different purpose as mentioned below.

\section{Flavonoids}

Total flavonoid was estimated by the protocol of Kevin et al. [13] with some modifications. $1 \mathrm{~g}$ of tissue was immersed in $4.0 \mathrm{ml}$ ethanol (80\%) for overnight. The extract obtained was filtered through Whatman filter paper no. 1 . The filtrate obtained was collected and stored at $4^{\circ} \mathrm{C}$ for future use. The ethanolic extract was diluted to ratio of $10: 1$ with $80 \%$ ethanol to make total volume $3.0 \mathrm{ml}$. Absorbance was taken at $362 \mathrm{~nm}$ using double beam ultraviolet-visible-1800 spectrophotometer, Shimadzu, Japan. All the readings were taken in triplicate and were calculated using quercetin (QE) as standard.

\section{Total phenolics}

Total phenolics content was estimated using Folin-Ciocalteu reagent with standard protocol and minor modifications [14-16]. $1 \mathrm{~g}$ of tissue was homogenized in $4.0 \mathrm{ml}$ ethanol $(70 \%)$. The extract was filtered using Whatman filter paper no. 1. Folin-Ciocalteu reagent was used to determine phenolic content. $2.0 \mathrm{ml}$ of the Folin-Ciocalteu reagent (diluted 1:10 with deionized water) and $0.5 \mathrm{ml}$ of the plant extract was mixed. $4.0 \mathrm{ml}$ of $\mathrm{Na}_{2} \mathrm{CO}_{3}$ solution $(7.5 \%, \mathrm{w} / \mathrm{v})$ was used to neutralize the reaction and kept for $30 \mathrm{~min}$. At $765 \mathrm{~nm}$ absorbance of the reaction, the solution was taken. The total phenolic content was determined using gallic acid (GA) as standard.

\section{Total carotenoid}

Total carotene content was estimated by the protocol of Sükran et al. [17]. Sample weighing $0.2 \mathrm{~g}$ was homogenized in $10 \mathrm{ml}(100 \%)$ acetone. The homogenate was then centrifuged at $2500 \mathrm{rpm}$ for $10 \mathrm{~min}$, using the REMI cooling centrifuge (model C-24BL). The absorbance of supernatant was taken at $470 \mathrm{~nm}$. The amount of carotene content was calculated according to the formulae of Lichtentaler et al. [18].

Total carotene $=1000 \mathrm{~A}_{470}-2.270 \mathrm{Ca}-81.4 \mathrm{Cb} / 227$.

Where, $\mathrm{Ca}=$ Chlorophyll $\mathrm{A}_{662 \mathrm{~nm}}$ and $\mathrm{Cb}=$ chlorophyll $\mathrm{B}_{646 \mathrm{~nm}}$.

\section{Total antioxidant activity}

Total antioxidant activity was determined by the protocol of Cacig et al. [19] with minor modifications. Sample weighing $1.0 \mathrm{~g}$ was homogenized in $4 \mathrm{ml}$ of double distilled water. The homogenate obtained was incubated for $24 \mathrm{~h}$ at $4^{\circ} \mathrm{C}$, and then filtered with Whatman filter paper no. 1 . In a $3 \mathrm{ml}$ glass cuvette, oxidative mixture of $0.18 \mathrm{ml}$ $\mathrm{KMnO}_{4} 0.01 \mathrm{M}, 0.42 \mathrm{ml} \mathrm{H}_{2} \mathrm{SO}_{4} 2 \mathrm{M}$, and $2.3 \mathrm{ml}$ distilled water was taken. $100 \mu \mathrm{l}$ of sample was added and the decrease in absorbance was measured at $535 \mathrm{~nm}$. Ascorbic acid was used as standard.

The following formula was used to quantify antioxidant activity:

$$
\text { A50 }=\text { tstandard } \times \frac{\text { Cstandard }}{\text { tplant sample }} \times \frac{\text { V standard }}{\text { mplant }} \times \frac{\text { Vextract }}{\text { Vplantsample }}
$$

Where:

A50 - antioxidant activity articulated, reflected in the time until the sample induces a decrease of the oxidizing agent $\left[\mathrm{KMnO}_{4}\right]$ concentration up to one half, compared against a standard [ascorbic acid] (mmol equivalent/g plant tissue).

t plant sample - the time until the sample induces a decrease of the permanganate concentration up to one half ( $\mathrm{min}$ ). t standard - the time until the standard (ascorbic acid) persuade a decline of the permanganate concentration up to one half $(\mathrm{min})[0.66 \mathrm{~min}$ as seen in standard curve].

C standard - standard (ascorbic acid) concentration [0.01 $\mathrm{mmol} / \mathrm{ml}]$. $\mathrm{m}$ plant - weight $(\mathrm{g})$ of the plant sample subjected for extraction $[1 \mathrm{~g}]$.

$\mathrm{V}$ plant sample - volume of the plant extract subjected for the analysis [0.1 ml].

V standard - volume of the standard subjected for the analysis [1 $\mathrm{ml}]$. $\mathrm{V}$ extract - volume (ml) of the obtained extract [ $4 \mathrm{ml}]$.

\section{Statistical analysis}

Results are expressed as mean \pm standard deviation. Correlation was established between antioxidants of different plants and different genera using MS Excel.

\section{RESULTS AND DISCUSSION}

Antioxidant capacity of five different plants of family Apocynaceae was studied. In this study, it was observed that total flavonoids content was maximum in $W$. tinctoria $(65.21 \pm 3.712 \mathrm{mg}$ equivalent $\mathrm{QE} / \mathrm{g}$ of tissue), while minimum was observed in C. gigantean $(9.17 \pm 1.125 \mathrm{mg}$ equivalent $\mathrm{QE} / \mathrm{g}$ of tissue) (Fig. 1). The effective antioxidant activities of flavonoids have been proposed to be accountable for protection against oxidative damage. Without a doubt laboratory investigations on flavonoids and other antioxidants propose their use in the treatment and prevention of various diseases [20].

When total phenolic content was estimated, it was found maximum in C. roseus ( $59.63 \pm 2.151 \mathrm{mg}$ equivalent $\mathrm{GA} / \mathrm{g}$ of tissue) and minimum was observed in C. gigantean (14.49 $\pm 1.174 \mathrm{mg}$ equivalent $\mathrm{GA} / \mathrm{g}$ of tissue) (Fig. 1). Plant phenolics are one of the important groups of secondary metabolites, acting as principal antioxidants or free radical scavengers [21]. Wide range of phenolic compounds has been isolated from C. roseus, which includes 2,3-dihydroxybenzoic acid, phenylpropanoids, cinnamic acid derivatives, and anthocyanins. These are responsible for its antioxidant property as well [22].

Total carotene content was found maximum in C. roseus $(70.91 \pm 4.41 \mu \mathrm{g} / \mathrm{g}$ fresh weight), minimum was found in A. scholaris (39.93 $\pm 2.52 \mu \mathrm{g} / \mathrm{g}$ fresh weight) (Fig. 1). Alkaloids of $C$. roseus have been studied by Punia et al. [23] where it was reported that over 130 alkaloids are found in this plant. The principal antioxidant property of carotenoids is due to singlet oxygen quenching, which fallouts in excited carotenoids that dispel the newly acquired energy through a series of interfaces with the solvent, thus coming back to the unexcited state and letting them to reduce more radical species. This can arise when the carotenoids had conjugated double bonds within them. Peroxyl radicals are the only free radicals that wholly destroy these pigments. Carotenoids are comparatively unreactive but may disintegrate and form non-radical compounds that may eradicate free radical attack by binding to these radicals [24].

Total antioxidant potential of the plants was also targeted which showed good activity. It was found that $C$. roseus $(0.846 \pm 0.109 \mathrm{mM}$ equivalent ascorbic acid/g tissue) showed maxima, while minima was observed in $W$. tinctoria $(0.461 \pm 0.046 \mathrm{mM}$ equivalent ascorbic acid/g tissue) (Fig. 1). A study by Rasool et al. [25] found C. roseus extracts and fractions as a viable source of natural antioxidants. It was observed that $C$. roseus shoots extracts and fractions exhibited good DPPH radical IC50, 28.2 to $119 \mu \mathrm{g} / \mathrm{ml}$. In another study, a comparison of antioxidant properties of $C$. roseus and Catharanthus alba was done, where it was found that the plant possesses a good antioxidant activity, furthermore, C. roseus had more antioxidant activity than C. alba [26]. When correlation was established between the antioxidants and different genera plants, a strong positive correlation was observed, indicating the family Apocynaceae as a potent source of antioxidants. The genus belonging to this family is a potent source of antioxidants (Table 1) indicating biochemical and genetic relationship, which can be a perspective for future research. 


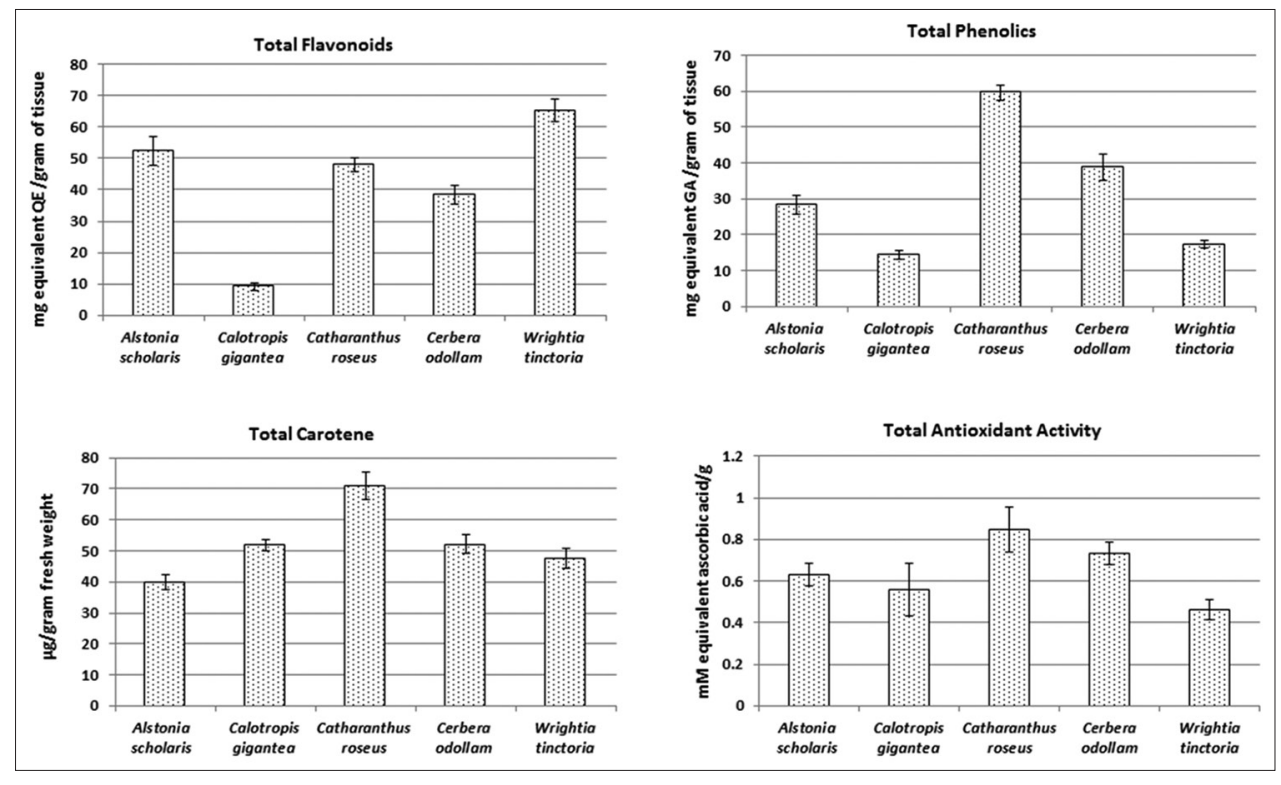

Fig. 1: Antioxidant potential of different plants of Apocynaceae family

Table 1: Correlation table of antioxidants between different plants of Apocynaceae family

\begin{tabular}{lllll}
\hline & A. scholaris & C.gigantea & C. roseus & C. odollam \\
\hline A. scholaris & 1 & & & \\
C. gigantea & 0.438036194 & 1 & 1 & \\
C. roseus & 0.780381905 & 0.752430544 & 0.988628885 & 1 \\
C. odollam & 0.850944511 & 0.762976803 & 0.620048729 & 0.726125132 \\
W. tinctoria & 0.95578804 & 0.41817973 & 1 \\
\hline
\end{tabular}

A. scholaris: Alstonia scholaris, C. gigantea: Calotropis gigantea, C. roseus: Catharanthus roseus, C. odollam: Cerbera odollam, W. tinctoria: Wrightia tinctoria

\section{CONCLUSION}

Results showed that the plants of family Apocynaceae are strong source of antioxidants, namely, carotene, flavonoids, and phenolics indicating its possible application in pharmacological products anticipated for improving standards of individuals. However, C. roseus showed considerably excellent antioxidant activity than other plants of same family, which can be used as an effective source to yield therapeutic biomolecules of pharmacological importance. Furthermore, it was observed that $W$. tinctoria plant is also a superior source of antioxidant in comparison to $C$. roseus plant. This family on a whole can be studied further for its medicinal values and can be exploited for good source of antioxidants. Moreover, it can be exploited by pharmaceutical and nutraceutical industry for healthy well-being.

\section{REFERENCES}

1. Madhuri S, Pandey G. Some anticancer plants of foreign origin. Curr Sci 2009;96:6

2. Peteros NP. Antioxidant and cytotoxic activities and phytochemical screening of four Phillppine medicinal plants. J Med Plant Res 2010;4:407-14.

3. Agbafor KN, Nwachukwu N. Phytochemical analysis and antioxidant property of leaf extracts of Vitex doniana and Mucuna pruriens. Biochem Res Int 2011;2011:459839.

4. Davies MJ. Identification of a globin free radical in equine myoglobin treated with peroxides. Biochim Biophys Acta 1991;1077:86-90.

5. Halliwell B, AruomaOI. DNA and Free Radicals. Chichester, England: Ellis Horwood, Division of Simon and Schuster Intl.; 1993.

6. Sies H. Glutathione and its role in cellular functions. Free Radic Biol Med 1999;27:916-21.

7. Sies H, Stahl W, Sundquist AR. Antioxidant functions of vitamins. Vitamins E and C, beta-carotene, and other carotenoids. Ann N Y Acad Sci 1992;669:7-20.

8. Endress ME and Bruyns PV. A revised classification of the apocynaceae s.1. Bot Rev 2000;66:1-56.
9. Phillipson JD. Phytochemistry and pharmacognosy. Phytochemistry 2007;68:2960-72.

10. Fabricant DS, Farnsworth NR. The value of plants used in traditional medicine for drug discovery. Environ Health Perspect 2001;109 Suppl 1:69-75.

11. Soejarto DD. Ethnographic component and organism documentation in an ethnopharmacology paper: A "minimum" standard. J Ethnopharmacol 2005;100:27-9.

12. Rapanarivo SH, Leeuwenberg AJ. Taxonomic revision of Pachypodium. Series of Revisions of Apocynaceac XLVIII. In: Rapanarivo SH, editor. Pachypodium (Apocynaceae): Taxonomy, Habitats and Cultivation. Rotterdam: Balkema; 1999. p. 1-82.

13. Kevin AL, Emmanuel G, Ellen P. Flavonoid Quantification in onion by spectrophotometric and high performance liquid chromatography analysis. Hortscience 2002;37:682-5.

14. Iqbal MS, Ansari MI, JafriS, PadmeshS, Ahmad I, Pandey B. Antioxidant potential of some medicinal plants (Ocimum sanctum, Azadirachta indica and Nigella sativa). Pharm Int Res J 2014;5:631-7.

15. Ragaa ES, Alaa SA, Mohammed AA, Ayman AG, Amira AA. Determination of phenolic components and antioxidant activity of some egyptian tea samples. Int J Pharm Pharm Sci 2015;7:198-202.

16. Arindam AG, Nishita DB, Anisha AK, Sneha SM, Michelle RM, et al. Antiproliferative, antioxidant activity and total phenolic content of Mitragyna parvifolia (roxb.) Korth. Int J Pharm Pharm Sci 2014;6:632-7

17. Sükran D, Tohit G, Rıdvan S. Spectrophotometric determination of chlorophyll-A, B and total carotenoid contents of some algae species using different solvents Tr. J Bot 1998;22:13-7.

18. Lichtenthaler HK, Wellburn AR. Determination of total carotenoids and chlorophylls A and B of leaf in different solvents. Biol Soc Trans 1985;11:591-2.

19. Cacig S, Szabo MR, Lupea AX, Ardelean A. Determination of the antioxidant activity of Ziziphus jujuba and Hydrangea incognita aqueous extracts. Studia Univ Vasile Goldis Seria St Vietii 2005;15:69-72.

20. Ayoola GA, Folawewo AD, Adesegun SA, Abioro OO, AdepojuBello AA, Coker HA. Phytochemical and antioxidant screening of some plants of Apocynaceae from South West Nigeria. Afr J Plant Sci 
2008;2:124-8.

21. Kähkönen MP, Hopia AI, Vuorela HJ, Rauha JP, Pihlaja K, Kujala TS, et al. Antioxidant activity of plant extracts containing phenolic compounds. J Agric Food Chem 1999;47:3954-62.

22. Natali RM, Robert V. Phenolic compounds in Catharanthus roseus. Phytochem Rev 2007;2:243-58.

23. Punia S, Jagjit K, Raman K, Kuldeep K. A medidinal plant with potent antitumor properties. Int J Res Ayurveda Pharm 2014;5:652-6.
24. Paiva SA, Russell RM. Beta-carotene and other carotenoids as antioxidants. J Am Coll Nutr 1999;18:426-33.

25. Rasool N, Rizwan K, Zubarr M, Kaleem RN, Imran I, Viqar-uddin A. Antioxidant potential of different extracts and fractions of Catharanthus roseus shoots. Int J Phytomed 2011;3:108-14.

26. Bhutkar MA, Bhise SB. Comparative studies on antioxidant properties of Catharanthus rosea and Catharanthus alba. Int J Pharmtech Res 2011;3:1551-6. 